\title{
Menciptakan Lingkungan Kaya Literasi Untuk Anak Sekolah Dasar
}

\author{
Nurhaliza \\ E-mail: nurhaliza2439@student.unri.ac.id \\ * Program Studi Pendidikan Bahasa dan Sastra Indonesia, Universitas Riau
}

\section{Pendahuluan}

Sekolah dasar adalah jenjang paling dasar pada pendidikan formal di Indonesia. Sekolah dasar ditempuh dalam waktu 6 tahun, mulai dari kelas 1 sampai kelas 6. Lulusan sekolah dasar dapat melanjutkan pendidikan ke tingkat SMP/SLTP. Pelajar sekolah dasar umumnya berusia 6-12 tahun. Literasi adalah istilah umum yang merujuk kepada seperangkat kemampuan dan keterampilan individu dalam membaca, menulis, berbicara, menghitung, dan memecahkan masalah pada tingkat keahlian tertentu yang diperlukan dalam kehidupan seharihari. Sehingga, literasi tidak bisa dilepaskan dari kemampuan berbahasa. Membentuk budaya minat baca dapat dilakukan sejak dini, lingkungan anak berpengaruh dalam menumbuhkan minat baca, salah satunya Sekolah. Menurut Darmono (2007): "Pada lingkungan sekolah, usaha pengembangan minat baca dapat dilakukan dengan prinsip jenjang dan pikat yaitu adanya usaha untuk memikat pengguna untuk mulai menyenangi kegiatan membaca dan upaya untuk mengkondisikan perlunya penyediaan materi bacaan yang sesuai dengan perkembangan peserta didik yang dapat memperkuat minat baca anak."

Menurut Kemendikbud (2016: 2), Pengertian Literasi Sekolah dalam konteks GLS adalah kemampuan mengakses, memahami, dan menggunakan sesuatu secara cerdas melalui berbagai aktivitas, antara lain membaca, melihat, menyimak, menulis, dan/atau berbicara. Gerakan Literasi Sekolah (GLS) adalah sebuah upaya yang dilakukan secara menyeluruh dan berkelanjutan untuk menjadikan sekolah sebagai organisasi pembelajaran yang warganya literat sepanjang hayat melalui pelibatan publik. GLS di Sekolah Dasar dilaksanakan 
secara bertahap dengan mempertimbangkan kesiapan masing-masing sekolah. Kesiapan ini mencakup kesiapan kapasitas fisik. sekolah (ketersediaan fasilitas, sarana, prasarana literasi), kesiapan warga sekolah (peserta didik, tenaga guru, orang tua, dan komponen masyarakat lain), dan kesiapan sistem pendukung lainnya (partisipasi publik, dukungan kelembagaan, dan perangkat kebijakan yang relevan).

\section{Pembahasan}

Sekolah merupakan tempat kegiatan belajar mengajar yang menyediakan sarana dan prasarana penunjang di dalamnya. Adapun lingkungan sekolah sangat berpengaruh bagi peserta didik dalam mengembangkan kegiatan belajar, terlebih lingkungan sekolah dapat memberikan dukungan dalam penumbuhan minat baca. Gerakan Literasi Sekolah adalah gerakan sosial dengan dukungan kolaboratif berbagai elemen. Upaya yang ditempuh untuk mewujudkannya berupa pembiasaan membaca peserta didik. Pembiasaan ini dilakukan dengan kegiatan 15 menit membaca (guru membacakan buku dan warga sekolah membaca dalam hati, yang disesuaikan dengan konteks atau target sekolah). Ketika pembiasaan membaca terbentuk, selanjutnya akan diarahkan ke tahap pengembangan, dan pembelajaran (disertai tagihan berdasarkan Kurikulum 2013). Variasi kegiatan dapat berupa perpaduan pengembangan keterampilan reseptif maupun produktif juga melibatkan warga sekolah, pemangku kepentingan, dan masyarakat bahwa gerakan literasi sekolah merupakan bagian penting dari kehidupan (Kemendikbud, 2016: 7-8).

Gerakan Literasi Sekolah dilaksanakan bertujuan untuk menumbuhkan budi pekerti peserta didik melalui pembudayaan ekosistem literasi sekolah guna menjadikan peserta didik menjadi memiliki budaya membaca yang tinggi serta kemampuan menulis (Kemendikbud, 2016: 2). Tujuan umum gerakan literasi sekolah yaitu menumbuh kembangkan budi pekerti peserta didik melalui pembudayaan ekosistem literasi sekolah yang diwujudkan dalam Gerakan Literasi Sekolah agar mereka menjadi pembelajar sepanjang hayat. 


\section{Tindakan yang Dilakukan}

\section{Menciptakan lingkungan kaya literasi}

\section{1) Perpustakaan SD}

Fungsi perpustakaan SD adalah sebagai pusat pengelolaan pengetahuan dan sumber belajar di SD yang dikelola oleh kepala SD yang dikelola oleh tim perpustakaan yang terdiri atas tenaga yang terlatih didalam pengelolaan bahan literasi.Perpustakaan SD sebaiknya dilengkapi oleh berbagai buku tidak hanya buku pembelajaran namun juga di lengkapi denggan majalan anak, komik, dongeng, karena fungsi lingkungan kaya literasi ialah menumbuhkan semangat membaca anak.

\section{2) Sudut Baca Kelas}

Sudut Baca Kelas adalah sebuah sudut di kelas yang dilengkapi dengan koleksi buku yang ditata secara menarik untuk menumbuhkan minat baca peserta didik digunakan untuk memajang koleksi bacaan dan karya peserta didik, berperan sebagai perpanjangan fungsi perpustakaan SD, yaitu mendekatkan buku kepada peserta didik. Sudut Baca Kelas dikelola oleh guru, peserta didik, dan orang tua.

\section{3) Area Baca}

Area baca meliputi lingkungan sekolah (koridor, halaman, kebun, ruang kelas, tempat ibadah, ruang UKS, ruang kepsek, ruang guru, ruang tunggu orang tua, dll.) yang dilengkapi oleh koleksi buku untuk memfasilitasi kegiatan membaca peserta didik dan warga sekolah.

\section{Sarana Sekolah}

Penyediaan sarana sekolah dimanfaatkan dengan penerapan literasi. Contoh bentuk kampanye yang di aplikasikan antara lain gaya hidup sehat bagi peserta didik dengan menyediakan wastafel di sudut halaman kelas yang disertai ajakan untuk mencuci tangan bagi warga sekolah. Kemudian pada taman dan tempat sampah, disediakannya kalimat persuasif berupa ajakan untuk merawat tanaman dan membuang sampah pada tempatnya. Selanjutnya di koridor tembok depan kelas 
sudah tersedianya ajakan untuk peserta didik agar selalu membaca. Pada kantin sekolah belum tersedianya himbauan atau kalimat persuasif untuk menjaga kebersihan, melarang untuk jajan sembarangan dan terlebih lagi dengan jajanan yang dijual di kantin haruslah sehat. Adapun belum tersedianya bentuk literasi di kantin diantisipasi dengan bentuk literasi yang berada di wastafel. Namun dengan keadaan seperti ini belum tentu siswa memperhatikan bentuk literasi yang sudah terpasang di lingkungan sekolah.

\section{Lingkungan kaya teks}

Lingkungan kaya teks di lingkungan sekolah dasar dimaksudkan agar siswa terbiasa membaca dan mengkaji apa yang ada disekitarnya. Teks-teks yang sengaja dikondisikan agar siswa dapat membaca yang berisi motivasi, berita, gambar, dll.

\section{Sarana Pendukung}
a. Sumbangan buku dari warga sekolah
b. Perpustakaan
c. Area membaca
d. Poster

\section{Tindakan Solutif}

Adapun dalam pelaksanaannya, terdapat langkah kegiatan dalam tahap pembiasaan, yaitu: Membaca 15 menit sebelum pelajaran dimulai

Kegiatan membaca 15 menit ini dibagi menjadi dua kegiatan, yaitu kegiatan membaca nyaring dan membaca senyap.

a.Membaca Nyaring

Kegiatan membacakan nyaring yang dilakukan yaitu tidak dilakukan oleh guru melainkan penerapan membaca langsung yang dilakukan oleh peserta didik dengan tujuan peserta didik mengenali suatu buku dan menerapkan kegiatan membaca secara langsung. Hal ini bertujuan untuk melatih kemampuan berbicara dan meningkatkan kelancaran membaca serta memahami isi bacaan. Membaca nyaring disesuaikan dengan masing-masing kelas sesuai tingkatan dan materi pembelajaran yang dimiliki. Bagi kelas rendah hal ini dilakukan dengan bertahap agar peserta 
didik dapat mempelajari serta memahami informasi baru dari materi yang dibaca. Untuk kelas tinggi yaitu dengan melatih menggunakan frasa yang tepat, membaca dengan tepat, membaca tanpa harus sering melihat kalimat yang dibaca. Adapun dalam teknis pelaksanaan membaca, peserta didik di minta membaca dengan lafal dan intonasi yang jelas namun dengan suara yang tidak terlalu keras, sehingga peserta didik memahami isi bacaan tersebut dan tidak mengganggu konsentrasi peserta didik lainnya. Kegiatan membaca ini tidak terlepas dari pengawasan guru. Guru memantau peserta didik dalam membaca yang setelah itu dari peserta didik dipilih salah satu untuk menerangkan isi cerita dari buku yang telah dibaca. Terdapat perbedaan pertanyaan pemahaman antara kelas rendah dan tinggi, dimana bagi kelas rendah hal yang dipertanyakan yaitu berdasarkan bentuk dan isi yang sederhana, kemudian untuk kelas tinggi yaitu lebih berpikir akan ide pokok cerita dan pesan moral yang disampaikan oleh pengarang.

\section{b.Membaca Senyap}

Kegiatan membaca senyap dilaksanakan 3 kali seminggu bergantian dengan membacakan nyaring. Teknis pada kegiatan membaca senyap yaitu guru membebaskan peserta didik untuk memilih buku bacaan sesuai keinginan yang tersedia di sudut baca kelas, kemudian peserta didik pun membaca dalam hati selama 15 menit. Membaca senyap yang dilakukan yaitu membaca cukup cepat namun dengan konsentrasi yang tinggi sehingga peserta didik akan memahami bacaanya. Guru memantau aktifitas peserta didik saat membaca. Selesai membaca, guru memberikan pertanyaan kepada peserta didik mengenai buku yang telah dibaca. Pada kegiatan membaca senyap, peserta didik memiliki catatan individu mengenai buku yang telah dibaca.

\section{Simpulan}

Gerakan Literasi Sekolah merupakan sebuah Penumbuhan minat baca tersebut dilakukan dalam beberapa tahapan yaitu Tahap Pembiasaan, Tahap Pengembangan, dan Tahap Pembelajaran. Pertama, Tahap Pembiasaan yang dilakukan yaitu mengadakan kegiatan wajib membaca buku non-pelajaran membuat bentuk kampanye kalimat persuasif yang dibuat di lingkungan sekolah. 
Kedua, Tahap Pengembangan yang dilakukan yaitu adanya kegiatan lanjutan dengan memberi tanggapan dari buku yang telah dibaca. Kegiatan yang dilaksanakan yaitu pengembangan literasi melalui kegiatan Bulan Bahasa. Ketiga, Tahap Pembelajaran yang dilakukan yaitu meningkatkan kemampuan literasi anak didalam kegiatan belajar mengajar dan juga memanfaatkan lingkungan sekolah seperti jam wajib kunjung perpustakaan. Hal ini dilakukan agar peserta didik dekat dengan perpustakaan dan memandang perpustakaan sebagai tempat yang menyenangkan untuk belajar. Ketiga tahap tersebut dapat menumbuhkan minat baca peserta didik dikarenakan disetiap kegiatan yang dilakukan yaitu menanamkan pembiasaan membaca pada pagi hari, penyediaan sarana dan prasarana literasi, kegiatan literasi dan kegiatan pemanfaatan koleksi perpustakaan yang dapat dijadikan sebagai bahan ajar. Program Gerakan Literasi Sekolah membiasakan anak gemar membaca menjadi salah satu contoh dimana setiap anak selalu dilatih dalam berpikir kritis, mampu memahami suatu persoalan, dapat menuangkan dalam suatu tulisan atau seni. 


\section{Referensi}

Antasari, Indah Wijaya. (2016). Peran pendidik dalam membentuk budaya baca anak. Dalam Moch. Mursyid(Ed.). Membumikan gerakan literasi di sekolah. Yogyakarta: Lembaga Ladang Kata bekerjasama dengan Pustaka Nun \& Azyan Publishing.

Arba'i, Jazimatul Husna. (2016). Menciptakan lingkungan literasi di rumah dan sekolah yang menyenangkan. Dalam Moch. Mursyid(Ed.). Membumikan gerakan literasi di sekolah. Yogyakarta: Lembaga Ladang Kata bekerjasama dengan Pustaka Nun \& Azyan Publishing.

Faizah, Dewi Utami dkk. (2016). Panduan gerakan literasi sekolah di sekolah dasar. Jakarta: Direktorat Jenderal Pendidikan Dasar dan Menengah Kemdikbud RI.

Setiawan, Rossie. (2016). Gerakan Literasi Sekolah. Jakarta: Satgas Gerakan Literasi Sekolah Dirjen Pendidikan Dasar dan Menengah Kemdikbud RI. Disampaikan pada kegiatan workshop Literasi Informasi di Sekolah tanggal 10 Agustus 2016 di Perpustakaan Kemdikbud RI Jakarta.

Rahim, Farida. (2011). Pengajaran Membaca di Sekolah Dasar Jakarta: Bumi Aksara.

Kemendikbud. (2016). "Desain Induk Gerakan Literasi Sekolah". http://dikdas.kemdikbud.go.id/index.php/des ain-induk-gls-kemendikbud/. $<$ diakses 4 Desember 2021>.

Kartika, Esther. 2004. Memacu Minat Membaca Siswa Sekolah Dasar. Jurnal Pendidikan Penabur (Nomor 03 tahun III): 113-128 
*Data Penulis

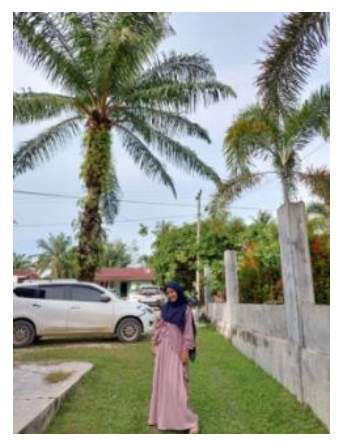

Nurhaliza, lahir di Pujud 4 Juni 2002. Alamat Kecamatan Pujud, Kabupaten Rokan Hilir, Provinsi Riau. Melanjutkan studi Strata Satu di Fakultas Keguruan dan Ilmu Pendidikan Program Studi Pendidikan Bahasa dan Sastra Indonesia Universitas Riau melalui jalur Seleksi Bersama Masuk Perguruan Tinggi Negeri (SBMPTN) 2020.

Kontak

HP/WA : 082284467994

Email : nurhaliza2439@student.unri.ac.id 